\title{
Androgen receptor levels during progression of prostate cancer in the trans- genic adenocarcinoma of mouse prostate model
}

\author{
Krisna Murti, ${ }^{1}$ Lisa M. Butler, ${ }^{2}$ Andrew Sakko, ${ }^{2}$ Carmela Ricciardelli, ${ }^{2}$ Tina B. Mitto, ${ }^{2}$ Alexandra Octnick, ${ }^{2}$ Jurgen \\ Stahl, ${ }^{3}$ Wayne D. Tilley. ${ }^{2}$ \\ ${ }^{1}$ Anatomical Pathology Department, Medical Faculty, University of Sriwijaya, Indonesia \\ ${ }^{2}$ Dame Roma Mitchell Cancer Research Laboratories, Hanson Institute, University of Adelaide \\ ${ }^{3}$ ClinPath Adelaide, South Australia.
}

\begin{abstract}
Abstrak
Tujuan Untuk menyusun konstruksi tissue microarrays (TMAs) dan mengevaluasi level reseptor androgen pada perkembangan kanker prostat dengan pemeriksaan imunohistokimia pada jaringan prostat tikus model the transgenic adenocarcinoma of mouse prostate (TRAMP) dan tikus non transgenik.

Metode Konstruksi tissue microarrays (TMAs) dilakukan terhadap sampel yang berasal dari lobus dorso-lateral tikus kelompok kontrol (non-transgenic), kelompok tanpa kastrasi (intact TRAMP) dan kelompok kastrasi (castrated TRAMP) yang di pulas dengan haematoxylin eosin (H\&E). Ekspresi reseptor androgen dievaluasi pada sampel TMAs dengan video image anlysis (VIA).

Hasil Ekspresi reseptor androgen dijumpai pada jaringan prostat normal maupun patologis baik pada lesi non-neoplastik maupun neoplastik sampai lesi ganas, sedangkan pada kanker prostat stadium lanjut ekspresi menurun atau menghilang. Ekspresi reseptor androgen meningkat pada kelompok kastrasi (kondisi pelucutan androgen) dibanding pada kelompok tanpa kastrasi.
\end{abstract}

Kesimpulan Sama seperti pada manusia, pada tikus TRAMP kanker prostat menunjukkan variasi ekspresi AR sampai kondisi castrate resistant, yang menunjukkan bahwa AR turut memfasilitasi pertumbuhan tumor lebih lanjut. (Med J Indones 2010; 19:5-13)

\begin{abstract}
Aim To construct tissue microarrays (TMAs) that consisted of prostate tumours from the transgenic adenocarcinoma of mouse prostate (TRAMP) mice and non-transgenic murine prostates and to assess androgen receptor (AR) levels during progression of prostate cancer in TRAMP mice by immunohistochemistry.

Methods Haematoxylin and eosin (H\&E) sections from the ventral and dorso-lateral prostate lobes of non-transgenic, intact TRAMP and castrated TRAMP were used to demarcate regions of interest for TMAs construction. The samples on TMAs were used to evaluate AR expression using video image analysis (VIA).

Results AR was expressed during cancer progression, but AR levels were reduced or absent in late stage disease. Furthermore, when AR levels were compared in tumours from intact and castrate animals, a significant increase in AR levels was observed following androgen ablation.

Conclusion Similar to clinical prostate cancer, in the TRAMP model, prostate tumours evolve mechanisms to maintain AR expression and AR responsive gene pathways following castration to facilitate continued tumour growth. (Med J Indones $2010 ; 19: 5-13)$
\end{abstract}

Key words : androgen ablation therapy, tissue microarrays, haematoxylin and eosin, video image analysis

Prostate cancer is the second most common malignant disease in men from Western communities and is the second highest cause of cancer related deaths in men. ${ }^{1}$ A critical issue in prostate cancer is the mechanism of failure of androgen ablation therapy (AAT), which is the only accepted systemic treatment for metastatic disease. While there is a very good response to AAT in about $90 \%$ of patients, the disease eventually relapses and progresses to castrate resistance.,

Correspondence email to: krisna.arinafril@daad-alumni.de
Castrate resistant prostate cancer is incurable and therefore is responsible for the majority of prostate cancer related deaths. While the underlying mechanisms of this conversion from hormone responsive to castrate resistant remain unknown, some mechanisms are emerging. Several studies have identified that the androgen receptor (AR), a critical component of the androgen signalling pathway, is expressed in both androgen-sensitive and castrate resistant prostate cancers. It is most likely that the $\mathrm{AR}$ continues to 
play an important role in prostate cancer progression, following failure of AAT. ${ }^{4,5}$

Investigation of the continuing role of AR signalling pathways in the progression of prostate cancer following AAT is limited by the availability to obtain clinical specimens representative of castrate resistant metastatic disease. Consequently, there has been considerable interest in the development of animal models that closely mimic the clinical disease. The transgenic adenocarcinoma of mouse prostate (TRAMP) model is uniquely suited to elucidate how the regulation of the androgen-signalling axis contributes to the progression of prostate cancer, as in TRAMP model, tumours arise spontaneously and follow a progression similar to that seen in humans. ${ }^{6}$

The aims of this research were 1) to construct tissue microarrays (TMAs) that contained prostate tumours that were collected from TRAMP mice and nontransgenic murine prostates and 2) to assess AR levels during progression of prostate cancer in TRAMP mice within the TMAs by immunohistochemistry.

\section{METHODS}

A cohort study on a TRAMP model was carried out from January to December 2005 in Dame Roma Mitchell Cancer Research Laboratories, Hanson Institute, University of Adelaide, South Australia.

\section{Animal cohorts and tumour grading}

Female TRAMP mice, maintained in a pure C57BL/6 background (Harlan Sprague Dawley, Inc., Indianapolis IN), were crossed with male non-transgenic FVB mice (Harlan Sprague Dawley, Inc., Indianapolis IN). [C57BL/6 TRAMP x FVB] F1 males non-transgenic and transgenic were generated from this cross. Transgenic mice were identified by a PCR-based screening assay using mouse tail DNA with primers as previously described. ${ }^{6}$ The TRAMP mice were divided into 2 cohorts:1) intact or non-castrated TRAMP mice, and 2) castrated TRAMP mice. A group of intact nontransgenic littermate mice were used as a control group. The non-transgenic and the intact TRAMP mice were divided into the following age groups: $8,10,12,14$, $16,18,20,22,24,26$, and 30 weeks. Intact TRAMP mice in which tumours were macroscopically visible and the lobes indistinguishable were separated into a sub-cohort of intact TRAMP mice with macroscopic tumours and analysed separately. The mice from this cohort were sacrificed at following time points: 16, $18,20,22,24,26$, and 28 weeks. Castrated TRAMP mice were castrated at 12 weeks of age, when prostate intra-epithelial neoplasia (PIN) is expected to develop, and designated as the castrated TRAMP mouse cohort. The mice were palpated on abdominal areas throughout prostate tumour development and the tumours from mice that were visible without palpitation were obtained by scarifying the mice at 18, 20,22, 24, 26, 28 and 30 weeks. Prior to sacrifice each mouse was anesthetised. Metastatic lesions were also harvested. All collected tissues were fixed in $10 \%$ formalin, embedded in paraffin blocks, and stained with haematoxylin and eosin (H\&E).

All prostatic tissues were histologically evaluated and graded by examining the H\&E sections under a light microscope according to an established pathology classification for genetically engineered mouse (GEM), which was also used to classify the pathology of prostate tumours in the present study. ${ }^{7}$ The pathological grading was assessed and analysed in both the dorso-lateral and ventral prostate and reviewed by two pathologists (KM and JS).

\section{Construction of tissue microarray blocks}

The analysed H\&E stained sections were used for the histopathology assessment and to demarcate regions of tissue of interest for the construction of a TMA block as previously describe. ${ }^{8}$ In this study we used $1.0 \mathrm{~mm}$ needles and $1.5 \mathrm{~mm}$ needles for larger tissues. Three orientation cores from mouse testis were placed in specific positions outside the geometric margins of the usually square or rectangular arrays to orient the whole microarray sections after they have been cut and also as positive controls for AR immunohistochemistry.

\section{Androgen receptor immunohistochemistry}

The TMA blocks were cut at $4 \mu \mathrm{m}$ sections then deparaffinized in xylene and sequentially rehydrated. Endogenous peroxide activity was quenched by incubating the slides with hydrogen peroxide. Complete antigen retrieval was carried out by microwaving the slides in $10 \mathrm{mM}$ citrate buffer ( $\mathrm{pH}$ 6.5), the slides were then incubated in a blocking solution. Further, the slides were incubated with sheep polyclonal AR antibody (U402-S; affinity purified rabbit antisera generated against amino acids 1 to 21 of the human AR) (made in Dame Rome Mitchel Cancer Research Laboratory, Australia) overnight. The slides were then subsequently washed in phosphate buffered saline (PBS) and incubated with secondary antibody, a 1/400 dilution of a biotinylated sheep anti-rabbit (Dako, Denmark) in blocking solution, followed by strepavidin horseradish complex (Dako, Denmark) (1/500 dilution in PBS). To generate a brown- 
insoluble deposit, slides were incubated with a mixture of diaminobenzidine tetrahydrochloride (DAB) $(50 \mathrm{mg} /$ $\mathrm{ml})$ and hydrogen peroxide $(0.06 \%)$. Sections were counterstained with weak Lillie-Mayer haematoxylin (1/10 dilution of strong haematoxylin), dehydrated in sequential absolute ethanol, cleared with xylene and mounted under glass cover slips.

\section{Androgen receptor immunostaining quantification}

Androgen receptor immunostaining quantification was done by video image analysis (VIA) and visual scoring.

\section{Video image analysis}

An Olympus BH-2 light microscope was connected to a computer-assisted colour image system (Video Pro 32 [R] Leading Edge Pty. Ltd., Adelaide South Australia) was used to examine AR immunostaining. All available glandular tissue containing tissue areas from TMA cores were captured using a digital camera under bright field microscopy at 40x objective magnification. An average of 10 images per section were randomly captured and analysed. The VIA measurements were restricted to the prostate glandular cell nuclei of normal glands, hyperplasia, PIN (without and with progression), adenocarcinomas either well differentiated (WD), moderately differentiated (MD) or poorly differentiated (PD) and metastatic tissues from lymph nodes. Measurements were done on the total area of analysed tissues (both positively and negatively stained nuclei) and the positively stained nuclei for an average 10 fields per triplicate cores. Every field was examined with a constant threshold setting for all fields using two wavelength interference filters, i.e. $550 \mathrm{~nm}$ and $436 \mathrm{~nm}$. The $550 \mathrm{~nm}$ filter was used to detect the present nuclei total number that covered the whole nuclear area and the $436 \mathrm{~nm}$ filter was used to detect and cover all DAB stained nuclei (brown area). Three parameters were measured for every section: (1) the integrated optical density per field (IOD) as an average $\mu \mathrm{m}$ of the optical densities for every positively stained pixel for 10 field sections, (2) the percentage of AR positive nuclei (DAB area per total area) multiplied by 100 , and (3) the mean optical density (MOD), which is the IOD per area of DAB staining (brown area).

The AR immunostaining was quantitated using VIA in the different lobes of the non-transgenic control mice and in all identified lesions in the intact and castrated TRAMP mice.

\section{Visual scoring}

To achieve consistency, the same images used for VIA were visually scored by an independent person who was unaware of the diagnosis and VIA scores. Results for AR immunoreactivity were represented as a percentage of positively stained nuclei per image field. From each section at least ten images were randomly taken and the percentage was averaged

\section{Data analysis}

Fisher's exact test was used to compare the differences in metastatic incidence between intact and castrated TRAMP mice. The differences in AR positive staining between the ventral and dorso-lateral lobes in the nontransgenic group, and the differences in AR staining in intact and castrated TRAMP macroscopic cohorts were compared using Wilcoxon ranked test. Moreover, Mann-Whiney-U test was performed to compare the AR staining in macroscopic tumour cohorts of castrated TRAMP and intact TRAMP mice, also to compare the AR staining in metastatic groups of castrated TRAMP and intact TRAMP mice. All analyses were performed with Statistical Product and Service Solutions (SPSS Version 11.5.0 Copyright 2004, SPSS Inc.). Data was accepted as statistically significant when $P<0.05$.

\section{RESULTS}

Histological features of every cohort can be seen on table 1 .

\section{Androgen receptor expression}

In this study, 207 tissue samples were analysed (Table 1), and from that number, 123 tissue samples were transferred into triplicate cores of TMA blocks then immunostained with AR. A total of $76 \%$ of the tissue samples ( 94 out of 123) were able to be analysed, 23 of which were normal, 10 were hyperplasia, 15 were PIN without progression, 4 were PIN with progression, 2 were WD adenocarcinoma, 2 were $\mathrm{MD}$ adenocarcinoma, 31 were $\mathrm{PD}$ adenocarcinoma, and 7 were metastatic PD adenocarcinoma. In $24 \%$ of cases (29 out of 123) no data was available due to specific tissue loss as a result of the antigen retrieval procedures or three-dimensional changes in the tissue core arrangement, including tissue damage or folding.

In the ventral and dorso-lateral lobes of intact TRAMP mice, the full spectrum of pathology were identified. Intact TRAMP mice with macroscopic tumours showed WD and PD adenocarcinomas, while castrated TRAMP mice showed 100\% PD adenocarcinoma. The incidence of metastases in castrated TRAMP mice was higher than those in intact TRAMP mice. 
Table 1. Classification of prostate pathologic progression in non-transgenic mice, intact and castrated TRAMP model.

\begin{tabular}{|c|c|c|c|c|c|c|}
\hline \multirow{3}{*}{$\begin{array}{c}\text { Classification of } \\
\text { pathology progression }\end{array}$} & \multicolumn{2}{|c|}{ Non-transgenic } & \multicolumn{3}{|c|}{ Intact TRAMP mice } & \multirow{2}{*}{$\begin{array}{c}\text { Castrated TRAMP } \\
\text { mice } \\
\begin{array}{c}\text { with macroscopic } \\
\text { tumour }\end{array}\end{array}$} \\
\hline & & & \multicolumn{2}{|c|}{$\begin{array}{c}\text { with } \\
\text { microscopic } \\
\text { tumours }\end{array}$} & $\begin{array}{c}\text { with macroscopic } \\
\text { tumour }\end{array}$ & \\
\hline & $\begin{array}{l}V \\
(n)\end{array}$ & $\begin{array}{l}\text { DL } \\
\text { (n) }\end{array}$ & $\begin{array}{l}\mathrm{V} \\
(\mathrm{n})\end{array}$ & $\begin{array}{l}\text { DL } \\
\text { (n) }\end{array}$ & (n) & (n) \\
\hline Normal & $\begin{array}{c}16 \\
(100 \%)\end{array}$ & $\begin{array}{c}16 \\
(94 \%)\end{array}$ & $\begin{array}{c}2 \\
(3 \%)\end{array}$ & $\begin{array}{c}2 \\
(3 \%)\end{array}$ & 0 & 0 \\
\hline Hyperplasia & 0 & $\begin{array}{c}1 \\
(6 \%)\end{array}$ & $\begin{array}{c}6 \\
(10 \%)\end{array}$ & $\begin{array}{c}10 \\
(15 \%)\end{array}$ & 0 & 0 \\
\hline PIN WoP & 0 & 0 & $\begin{array}{c}16 \\
(26 \%)\end{array}$ & $\begin{array}{c}19 \\
(29 \%)\end{array}$ & 0 & 0 \\
\hline PIN WP & 0 & 0 & $\begin{array}{c}17 \\
(28 \%)\end{array}$ & $\begin{array}{c}13 \\
(20 \%)\end{array}$ & 0 & 0 \\
\hline WD AC & 0 & 0 & $\begin{array}{c}13 \\
(21 \%)\end{array}$ & $\begin{array}{c}15 \\
(23 \%)\end{array}$ & 1 & 0 \\
\hline MD AC & 0 & 0 & 0 & $\begin{array}{c}2 \\
(3 \%)\end{array}$ & 0 & 0 \\
\hline PD AC & 0 & 0 & $7(12 \%)$ & $4(6 \%)$ & $26(96 \%)$ & $21(100 \%)$ \\
\hline Total & 16 & 17 & 61 & 65 & 27 & 21 \\
\hline Total Metastasis & & & & & $18 / 27(67 \%)$ & $18 / 21(86 \%)$ \\
\hline
\end{tabular}

$\mathrm{PIN}=$ prostate intra-epithelial neoplasia, $\mathrm{WoP}=$ without progression, $\mathrm{WP}=$ with progression, $\mathrm{WD}=$ well differentiated, $\mathrm{AC}=\mathrm{adenocarcinoma}, \mathrm{MD}=$ moderately differentiated, $\mathrm{PD}=$ poorly differentiated, $\mathrm{V}=$ ventral, $\mathrm{DL}=$ dorso-lateral

\section{Androgen receptor expression in non-transgenic mice}

In the prostate of non-transgenic mice, nuclear AR immunoreactivity was observed in the majority of epithelial and stromal cells. This AR expression was heterogenous even though most of the sections were normal (Figures $1 \mathrm{~A}$ and $\mathrm{B})$. We also observed that $\mathrm{AR}$ expression was heterogenous in the different prostatic lobes.

\section{Androgen receptor expression in intact TRAMP mice}

In intact TRAMP mice, AR expression was identified in the nuclei of normal, hyperplasia, PIN, and WD adenocarcinoma prostate cells (Figures 1 B-F). Further, AR expression was variable in the two MD tumours. In PD adenocarcinoma, where normal glands were trapped among cancer cells, a difference in AR expression was observed. The expression of AR in normal trapped glands showed strong intensity while the adjacent cancer cells showed variable weak to negative AR expression (Figure $1 \mathrm{G}$ ). Moreover, PD adenocarcinoma sections of localised prostatic lobes $(n=4)$ demonstrated various weak to negative AR expression compared to non-tumour lesions and WD to MD adenocarcinoma. In addition, AR expression in the prostates of mice with PD macroscopic tumours also varied from weak to negative regardless of the mouse age.

\section{Androgen receptor expression in metastatic samples}

In metastatic prostate tumour samples, AR expression was also variable weak to negative in the majority of sections either from intact or castrated TRAMP mice. 

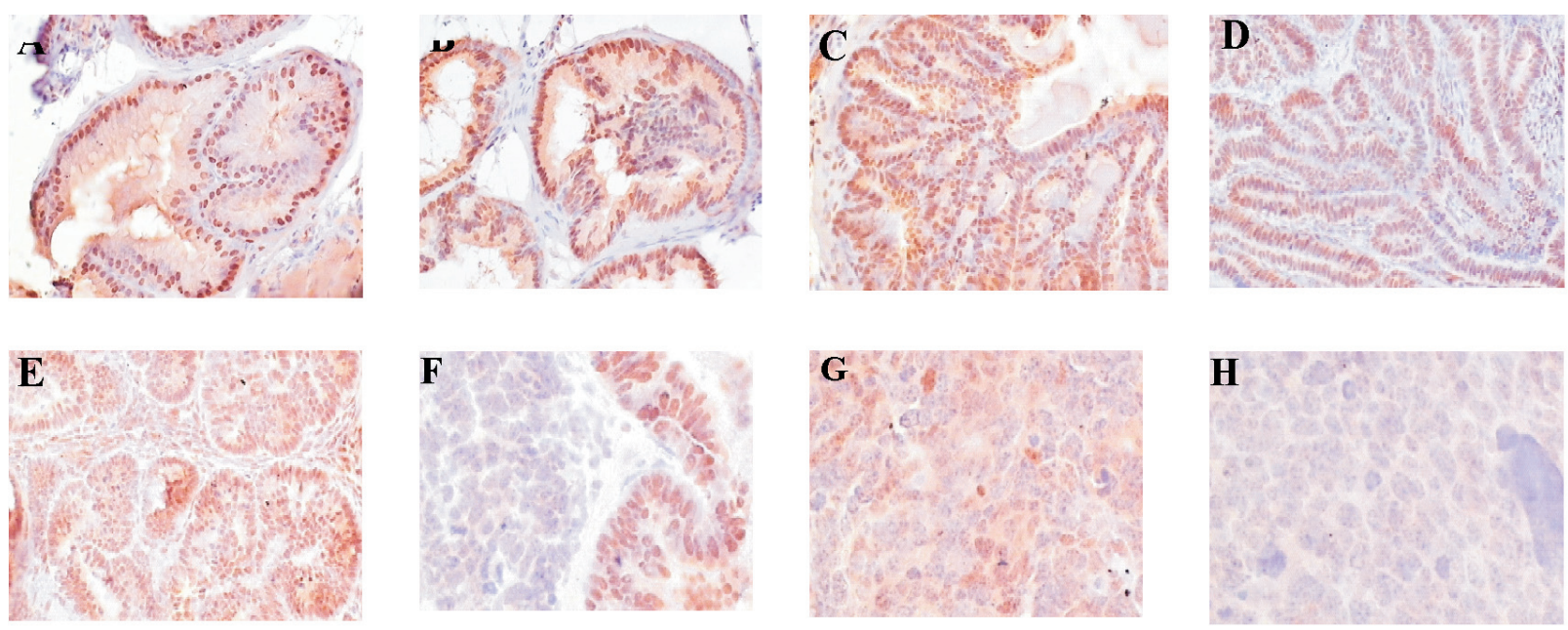

Figure 1. AR expression in various pathology lesions from non-transgenic, intact TRAMP and castrated TRAMP mice. A. In the normal prostate gland. B. In hyperplasia of intact TRAMP mouse. C. In PIN with progression from an intact TRAMP mouse. D. In WD tumour from an intact TRAMP mouse. E. In MD adenocarcinoma from an intact TRAMP mouse. F. In PD tumour section from an intact TRAMP mouse. G. Heterogenous AR expression on PD tumour from a castrated TRAMP mouse. H. In lymph node metastatic section from the same mouse as in Figure G. A- E, 20x objective magnification. F- H, 40x objective magnification.

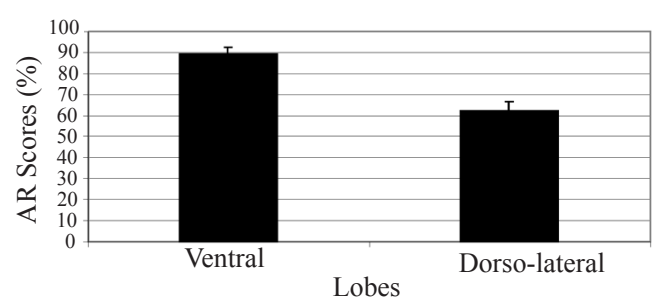

Figure 2. Average AR score by VIA in non-transgenic mice

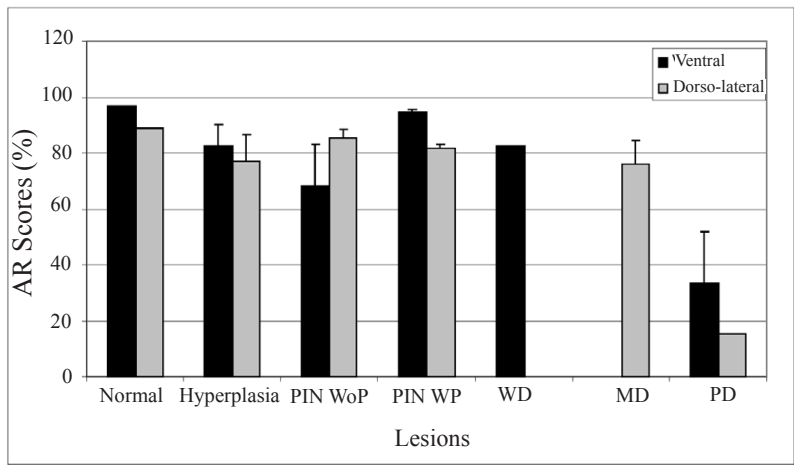

Figure 3. Average AR scores by VIA in ventral and dorso-lateral lobes of microscopic lesions of intact TRAMP mice.

$\mathrm{PIN}$ WoP $=$ PIN without progression, $\mathrm{PIN}$ WP $=\mathrm{PIN}$ with progression, $\mathrm{WD}=$ well differentiated, $\mathrm{MD}=$ moderately differentiated, $\mathrm{PD}=$ poorly differentiated

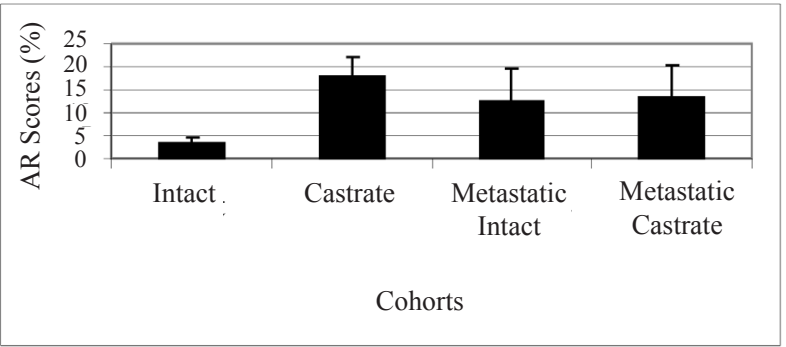

Figure 4. Average AR scores in the prostate lobe of intact and castrated TRAMP mice with macroscopic and metastatic tumours.

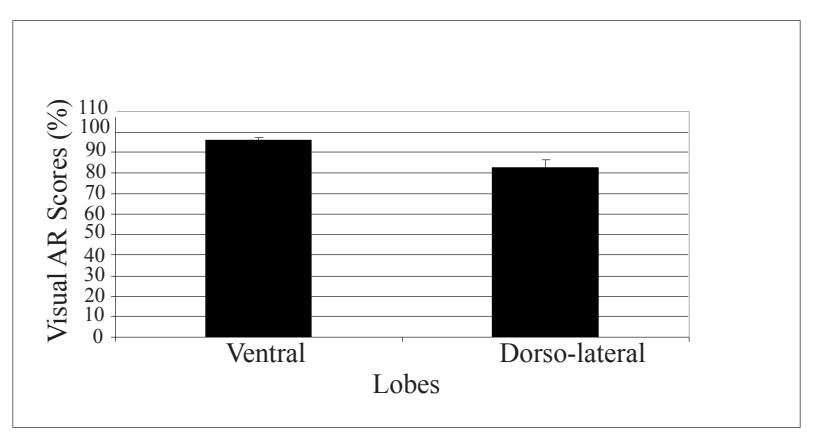

Figure 5. Average visual AR scores in non-transgenic mice 


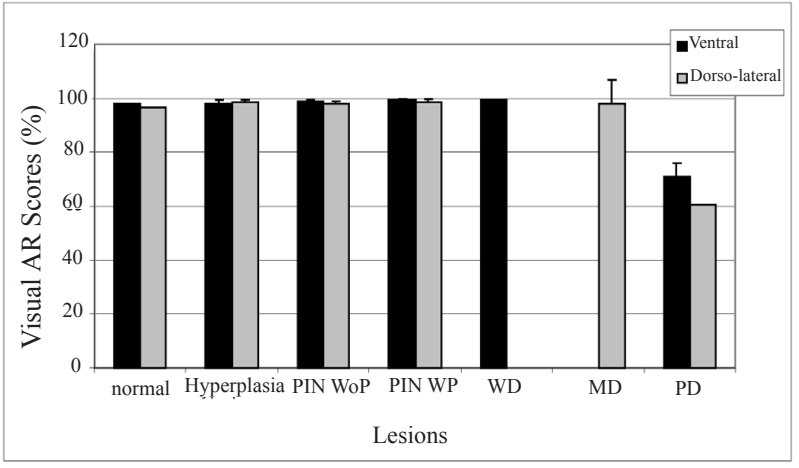

Figure 6. The average visual AR scores in the ventral and dorsolateral lobes of intact TRAMP mice

$\mathrm{PIN}$ WoP $=$ PIN without progression, $\mathrm{PIN} \mathrm{WP}=\mathrm{PIN}$ with progression, $\mathrm{WD}=$ well differentiated, $\mathrm{MD}=$ moderately differentiated, $\mathrm{PD}=$ poorly differentiated

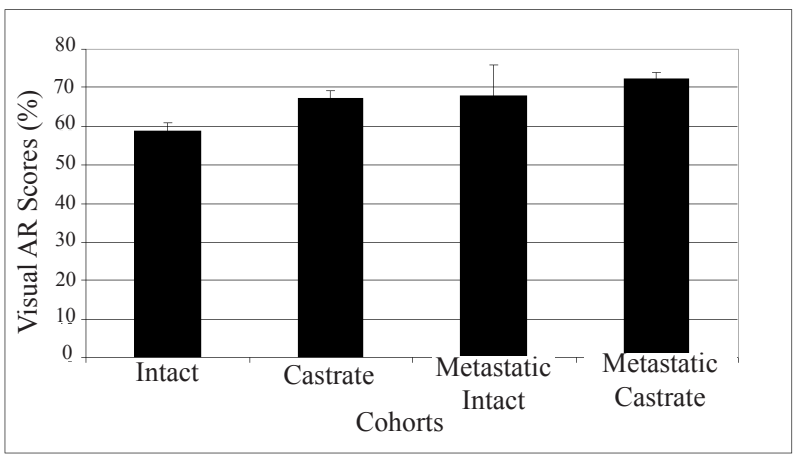

Figure 7. Average visual AR scores in intact and castrated TRAMP mice with macroscopic and metastatic tumours

Androgen receptor expression in castrated TRAMP mice

Allsections from thiscohortexhibitedPDadenocarcinomas and AR expression that was heterogenous. The majority of sections showed variable weak to negative AR expression regardless of the age of the mice (Figure $1 \mathrm{H}$ ). Areas that displayed a small cell carcinoma variant showed weak to negative AR expression (Figures $1 \mathrm{~J}-\mathrm{L}$ ). In a few sections, some areas showed weak AR expression both in the nuclei and cytoplasms (Figures $1 \mathrm{~J}$ and L).

\section{Quantification of AR immunostaining using VIA}

\section{Non-transgenic mice}

The average AR score in non-transgenic mice showed a significant difference between the ventral and dorsolateral lobes. The average AR score in the ventral lobe was higher than in dorso-lateral lobe $(P=0.012)$ (Figure 2).

\section{Intact TRAMP mice with microscopic lesions}

In this cohort, no difference in AR score pattern between the ventral and dorso-lateral lobes was observed (Figure 3). In the ventral lobe, the average AR score in normal ( $\mathrm{n}=$ 1), hyperplasia $(n=3)$, PIN without progression $(n=5)$, PIN with progression $(\mathrm{n}=2)$, and WD adenocarcinoma $(n=1)$, showed consistently higher average AR scores than observed in the PD adenocarcinoma $(n=3)$ (Figure $3)$. In the dorso-lateral lobes, the average AR scores in normal $(\mathrm{n}=1)$, hyperplasia $(\mathrm{n}=6)$, PIN without progression $(n=7)$, PIN with progression $(n=2)$ and MD adenocarcinoma $(n=2)$ showed relatively similar AR scores. However, the average AR score in PD adenocarcinoma $(\mathrm{n}=1)$ significantly decreased compared to other lesions (Figure 3).

\section{Mice with macroscopic tumours and metastatic lesions}

The average AR imunostaining in the prostates of castrated TRAMP mice with macroscopic tumours ( $\mathrm{n}=$ 14) was significantly increased compared to the average of AR immunostaining scores in intact TRAMP mice $(n=13)$. There was a significant difference of AR score between castrated and intact TRAMP mice without metastatic tumours $(P=0.000)$. In contrast, the average AR staining in metastatic groups showed no difference $(P=0.857)$ between castrated $(\mathrm{n}=4)$ and intact TRAMP $(\mathrm{n}=3)$ mice (Figure 4).

\section{Visual Scoring}

\section{Non-transgenic mice}

Wilcoxon signed ranks test showed that the average visual AR scores in non-transgenic mice were significantly different between the ventral and dorsolateral lobes, with AR scores being higher in the ventral lobe compared to the dorso-lateral lobe $(P=0.012)$ (Figure 5). This is consistent with the measurement made using VIA.

\section{Intact TRAMP mice with microscopic lesions}

In intact TRAMP mice with microscopic lesions no difference in the AR score of the ventral and dorsolateral lobes and in the pattern of both lobes were observed (Figure 6). In the ventral lobe, the average AR scores in normal $(n=1)$, hyperplasia $(n=3)$, PIN without progression $(n=5)$, PIN with progression $(n=$ $2)$, and WD adenocarcinoma $(n=1)$, showed relatively similar AR scores. However, the average AR score in PD adenocarcinoma $(n=3)$ was decreased compared to the other lesions. 
In the dorso-lateral lobe, the average AR scores in normal $(n=1)$, hyperplasia $(n=5)$, PIN without progression $(n=7)$, PIN with progression $(n=2)$, and MD adenocarcinoma $(\mathrm{n}=2)$ showed relatively similar AR score. Similarly to that observed in the ventral lobe, the average $\mathrm{AR}$ score in $\mathrm{PD}$ adenocarcinoma $(\mathrm{n}=1)$ was decreased compared to the other lesions (Figure 6).

\section{Macroscopic tumours in TRAMP mice with metastatic tumours}

The average visual AR imunostaining scores in castrated TRAMP mice with macroscopic tumours $(n=14)$ was significantly increased $(P=0.027)$ compared to the average of AR scores in intact TRAMP mice with macroscopic tumours $(n=13)$. The visual AR staining in metastatic group, however, showed no difference between castrated and intact TRAMP mice $(P=0.857)$ (Figure 7).

\section{DISCUSSION}

A critical issue in human prostate cancer is the rapid progression of the disease after failure of AAT, indicative of castrate resistant tumour growth. Resistance to AAT is not necessarily due to loss of androgen sensitivity of the tumour cells, but may develop as a consequence of a deregulated androgen-signalling axis resulting from increased sensitivity of AR activation or structural alterations in the AR gene. ${ }^{4}$ Thus it appears that prostate cancers evolve mechanisms to maintain AR expression and AR responsive gene pathways following AAT, and these mechanisms play a key role in the failure of AAT. Furthermore, AR heterogeneity is often seen in human prostate cancer and has been proposed as a prognostic factor for hormonal therapy. ${ }^{9-12}$ Therefore, AR immunochemistry was used to determine the AR status in the TRAMP mice. Previous studies suggested 2 assessments to be performed; computerised video image analysis (VIA) and visual examination. Computerized VIA objectively quantitates AR, while visual examination is more subjective. ${ }^{9}$

Preliminary studies using the TRAMP model showed that AR staining was expressed in the nuclei of luminal epithelial cells and that expression was heterogenous in the stromal compartment of the mouse prostate. In contrast, the AR exhibits weak or no staining in the majority of MD or PD prostate cancer. ${ }^{6,13-15}$

In comparison, a study of human prostate cancer demonstrated that there was a considerable increase in the heterogeneity of AR immunostaining in prostate cancer cells compared to non-malignant lesions. ${ }^{16}$ Other studies have found that normal prostate cells exhibit greater homogeneity of AR immnunostaining. ${ }^{11,17}$ Furthermore, a study identified that AR was expressed both in relapsed and metastatic prostate cancer. ${ }^{18}$

Similar to previous data in the human prostate and TRAMP mouse prostate, in the present study we observed that AR was expressed throughout nonmalignant prostate lesions in addition to $\mathrm{WD}$ and MD adenocarcinomas. We also observed that the AR exhibited weak or no expression in PD prostate cancers from either PD primary or metastatic adenocarcinoma. Taken together, AR immunostaining in the TRAMP model demonstrated similar AR expression patterns to human prostate tissues.

The use of VIA enables quantification of $A R$ levels detected by immunohistochemistry. The AR immunostaining can be used to predict response to endocrine therapy and prostate cancer patient survival. 10,11,19 Moreover, data from Ricciardelli et al. (2005) showed that the assessment of AR levels and its cellular distribution can be used as an indicator of disease stage prior to surgery. ${ }^{20}$ Similar results were achieved by Henshall et al. (2001) in which AR was found to be expressed in more than $70 \%$ of malignant cells, but in the adjacent peritumoral stroma AR was found to be expressed at very low levels. ${ }^{21}$ This data correlated with higher-grade prostate cancers, poorer prognosis and a high possibility that the cancer would relapse following radical prostatectomy. Furthermore, VIA has also been used for quantification of AR staining in TRAMP mice. Their data showed that AR expression in the prostates of TRAMP mice was consistent with that observed in the human prostate. ${ }^{6,13}$

We measured AR staining by VIA in the ventral and dorso-lateral prostate lobes of non-transgenic mice and the results showed consistency with the visual assessment, i.e. the average AR score in the ventral lobe was higher than in the dorso-lateral lobes. Concordance between VIA and visual scoring of AR levels was also achieved in intact TRAMP mice with microscopic lesions, with the exception of mice exhibiting PD adenocarcinoma, in which AR was heterogeneously expressed. The main inconsistency between VIA and visual measurement in PD adenocarcinoma either in microscopic lesions or in macroscopic tumours pertained to the percentage of positive AR staining. Visual scoring calculates the percentage of positively 
stained brown nuclei per field of image regardless of the intensity of the staining (i.e. either weak, moderate or strong), whereas, VIA measures the intensity of positively stained nuclei. The difference may explain why the visual scoring of AR staining were considerably higher than the VIA measurements in the same sections. In contrast to the tumours, AR quantification by VIA and visual scoring in benign lesions from normal, hyperplasia and PIN without progression to WD and MD adenocarcinoma was more or less consistent. In addition, both methods of quantification demonstrated higher levels of AR immunostaining in benign lesions and WD compared to PD adenocarcinoma. These findings were analogous to other studies both in the TRAMP model and in human prostate cancer. ${ }^{6,12}$ These data suggest that during tumour progression, particularly in advanced prostate cancer, increased genetic instability and the development of altered androgen sensitivity may have occurred.

It was fascinating to observe that in TRAMP mice with macroscopic tumours, quantification of $\mathrm{AR}$ staining in primary tumours of castrated TRAMP mice revealed higher levels of AR than in intact TRAMP mice. This finding indicates that castration most likely promotes growth of androgen sensitive prostate cells in the TRAMP model. This finding is consistent with recent evidence suggesting that castration selects for hyperactive AR signalling pathway in clinical prostate cancer, possibly by increasing the expression of key co-regulators that enhance AR function. In contrast, quantification of AR staining in metastatic lesions showed no difference between the intact and castrated TRAMP mice. The difference response of AR quantification between the primary tumour in intact and castrated TRAMP mice and their metastases could be associated with differences in microenvironment between both treatments and conditions. The underlying mechanism for these observations is not understood, but is in agreement with other reports which found that in the castrated state AR signalling pathways are already activated after castration, thereby preserving the role of $\mathrm{AR}$ through tumour progression to the metastatic state. ${ }^{22}$ In prostate cancer cells that are not subjected to AAT, AR expression is reduced or lost in PD cancer. However, it appears that AR regulated signalling pathways are re-activated during prostate cancer progression to metastatic disease. ${ }^{12,15}$

Video image analysis has been used by many studies to predict the outcome of AAT, ${ }^{9,11,19}$ Using AR immunostaining with computer-assisted VIA techniques, we measured quantitative differences in AR expression in various prostate lesions. Video image analysis can only be an objective device if it used consistently and with an appreciation of its inherent errors. The processes in VIA involves several basic steps, in which every step must be performed as consistently and carefully as possible. The critical component is to set up optimal thresholds for every specimen and to use consistent criteria. It is often impossible to adjust the threshold perfectly due to the highly heterogenous nature of some specimens making the threshold setting a major source of error. In this study, we attempted to minimize the effect of the threshold setting by repeating the measurement with multiple threshold setting and in some cases, using a second person with experience in VIA to confirm the threshold setting. The main consequence of threshold setting is to alter the assessment of AR staining intensity, which could explain differences between VIA and visual scoring of AR levels.

In this study we observed that AR was also expressed in the cytoplasm rather than nucleus of the stromal compartment of the TRAMP prostate. Although there is not much data to explain whether these observations are correlated to prostate tumour development or progression, it is possible that AR expression in the stroma adjacent to tumours in localised prostate cancer influences disease progression. ${ }^{20,21}$ It is plausible that stromal components in the normal prostate confer a predilection for tumorigenesis. A specific interaction between cancer cells and their microenvironment is required for prostate cancers to progress to metastatic and castrate resistant disease. The prostatic stroma, including extracellular matrix appears to be involved with endocrine, autocrine and paracrine mechanisms in the regulation of cancer progression. ${ }^{23,24}$ Further elucidation of the molecular mechanisms underlying the interactions between tumour cells and the surrounding stroma and the role of AR in regulating the stromal interactions may result in a better understanding of prostate cancer progression and lead to improvements in therapeutic management of this disease.

Taken together, all the data from our findings based on the quantification of AR expression levels and other studies support the concept that AR signalling pathways are still utilised or up-regulated in cancer cells that regrow after castration. It appears that the activation of androgen-regulated genes in a castrate state is adequate to sustain tumour growth. ${ }^{4,22,25}$ The increase in AR protein levels in tumour cells following castration could sensitise the tumour to low levels of ligand. However, it is also possible that different types 
of prostate cancer cells with stem-cell properties that are resistant to AAT might be present from the beginning of the biological history of this cancer. The AAT may then select and trigger the growth of an androgen independent population that is already present together with the androgen dependent cell population. ${ }^{13,25}$

In conclusion, the findings of this study suggest that similar to clinical prostate cancer, in the TRAMP model, prostate tumours evolve mechanisms to maintain AR expression and AR responsive gene pathways following castration thereby facilitating continued tumour growth. The assessment of AR staining in prostate cancer tissues using TMAs followed by VIA is a potentially powerful method to predict disease progression and response to hormone therapy. The use of TMAs comprising TRAMP tissues at different stages of disease progression and treatment response will facilitate molecular and cellular analyses.

\section{REFERENCES}

1. Taplin ME, Balk SP. Androgen receptor: a key molecule in the progression of prostate cancer to hormone independence. J Cell Biochem. 2004; 91: 483-90.

2. Grossmann ME, Huang H, Tindall DJ. Androgen receptor signalling in androgen-refractory prostate cancer. J Natl Cancer Inst. 2001; 93:1687-97.

3. Denmeade SR, Isaacs JT. Development of prostate cancer treatment: the good news. Prostate 2004; 58: 211-24.

4. Tilley WD, Buchanan G, Coetzee GA. Androgen receptor signalling in prostate cancer. In: Henderson BE, Ponders BA, Ross RK, editors. Hormones, genes, and cancer. New York: Oxford University; 2003.

5. Suzuki H, Ueda T, Ichikawa T, Ito H. Androgen receptor involvement in the progression of prostate cancer. Endocr Relat Cancer. 2003; 10: 209-16.

6. Pienta KJ, Abate-Shen C, Agus DB, Attar RM, Leland WK, Chung LWK, et al. The Current state of preclinical prostate cancer animal models. Prostate. 2008; 68: 629-39.

7. Shappell SB, Thomas GV, Roberts RL, Herbert R, Ittmaan MM, Rubin MA, et al. Prostate pathology of genetically engineered mice: definitions and classification. The consensus report from the Bar Harbor meeting of the mouse models of human cancer consortium prostate pathology committee. Cancer Res. 2004; 64: 2270-305.

8. Mobasheri A, Airley R, Foster CS, Tanzil GS, Shakibaei. Post-genomic applications of tissue microarrays: basic research, prognostic oncology, clinical genomics and drug discovery. Histol Histopathol. 2004; 19: 325-35.

9. Mohler JL, Gregory CW, Ford III OH, Kim D, Weaver $\mathrm{CM}$, Petrusz $\mathrm{P}$, et al. The androgen axis in recurrent prostate cancer. Clin Cancer Res. 2004; 10: 440-8.

10. Feldman BJ, Feldman D. The Development of androgenindependent prostate cancer. Nature Rev. 2001: 1; 34-45.
11. Buchanan G, Irvine RA, Coetzee GA, Tilley WD. Contribution of the androgen receptor to prostate cancer predisposition and progression. Cancer Meta Rev. 2001; 20: 207-23.

12. Li R, Wheeler T, Dai H, Frolov A, Thompson T, Ayala G. High level of androgen receptor is associated with aggressive clinicopathologic features and decreased biochemical recurrence-free survival in prostate. Am J Surg Pathol. 2004; 28: 928-34.

13. Morgenbesser SD, McLaren RP, Richards B, Zhang M, Akmaev VR, Winter SF, et al. Identification of genes potentially involved in the acquisition of androgenindependent and metastatic tumor growth in an autochthonous genetically engineered mouse prostate cancer model. Prostate. 2007: 67; 83-106.

14. Kaplan-Lefco PJ, Chen TM, Ittmann MM, Barrios RJ, Ayala GE, Huss WJ, et al. Pathobiology of autochthonous prostate cancer in a pre-clinical transgenic mouse model. Prostate. 2003; 55: 219-37.

15. Wikstrom P, Lindahl C, Bergh A. Characterization of the autochthonous transgenic adenocarcinoma of the mouse prostate (TRAMP) as a model to study effects of castration therapy. Prostate. 2005; 62: 148-64.

16. Culig Z, Klocker H, Bartsch G, Steiner H, Hobisch A. Androgen receptors in prostate cancer. J Urol. 2003; 170: 1363-69.

17. Segawa N, Nakamura M, Shan L, Utsunomiya H, Nakamura Y, Mori I, et al. Expression and somatic mutation on androgen receptor gene in prostate cancer. Int J Urol. 2002; 9: 545-53.

18. Culig Z, Klocker H,-Bartsch G, Hobisch A. Androgen receptor mutations in carcinoma of the prostate: significance for endocrine therapy. Am J Pharmaco Genom. 2001; 1: 241-9.

19. Gaston KE, Kim D, Singh S, Ford III OH, Mohler JL. Racial differences in androgen receptor protein expression in men with clinically localized prostate cancer. J Urol. 2003; 70: 990-3.

20. Ricciardelli C, Choong CS, Buchanan G, Vivekanandan S, Neufing P, Stahl J, et al. Androgen receptor levels in prostate cancer epithelial and peritumoral stromal cells identify nonorgan confined disease. Prostate. 2005; 63: 19-28.

21. Henshall SM, Quinn DI, Lee SL, Head DR, Golovsky $\mathrm{D}$, Brenner PC, et al. Altered expression of androgen receptor in the malignant epithelium and adjacent stroma is associated with early relapse in prostate cancer. Cancer Res. 2001; 61: 423-7.

22. Scher HI, Buchanan G, Gerald W, Butler LM, Tilley WD. Targeting the androgen receptor: improving outcomes for castration-resistant prostate cancer. Endocr Relat Cancer. 2004; 11: 459-76.

23. Cunha GR, Hayward SW, Wang YZ, Ricke WA. Role of the stromal microenvironment in carcinogenesis of the prostate. Int J Cancer. 2003; 107: 1-10.

24. Barclay WW, Woodruff RD, Hall MC, Cramer SD. A system for studying epithelial-stromal interactions reveals distinct inductive abilities of stromal cells from benign prostatic hyperplasia and prostate cancer. Endocrinology. 2005; 146: 13-8.

25. N, Triaspolitica. "Mengenal Penyakit Kanker, Jenis, Gejala, Penyebab Berikut Pengobatan Kanker." Mau Nanya Dong Dok. N.p, 20 June 2017. Web. 28 June 2017. $<$ https://nanyadongdok.blogspot.com/2017/06/mengenalpenyakit-kangker-jenis-gejala.html $>$. 